\title{
The effect of selection for protein and isozyme loci on quantitative traits in a doubled haploid population of barley
}

W. Powell,

R. P. Ellis,

M. Macaulay,

J. McNicol and

B. P. Forster
Scottish Crop Research Institute, Invergowrie, Dundee DD2 5DA, U.K.

Doubled haploid families extracted from the $F_{1}$ hybrid of the spring barley cross (Dissa $\times$ Sabarlis) by the Hordeum bulbosum technique were scored for the segregation of alleles at isozyme loci. Isozyme and protein loci on all seven pairs of barley chromosomes were examined and five out of the seven pairs of barley chromosomes (2I, 3I, 4I, 6I and 7I) were shown to possess polymorphic isozyme and protein loci. The systems tested did not deviate significantly from the expected 1:1 ratio and esterase loci on chromosome 3 were mapped intra-chromosomally. The relationship between marker loci and quantitative trait loci (QTL) was examined. A comparison of the mean scores for each allelic class revealed significant differences in the expression of a range of quantitative traits. Thus, by selecting for isozyme and protein phenotypes one can significantly affect the expression of certain QTL in barley. For example, allelic variation at the $\alpha$-Amy-1 locus makes a large contribution to the genetic variation available for selection in the case of single plant yield. The advantage of using DH families for gene mapping and in dissecting QTL are discussed.

\section{INTRODUCTION}

The dissection and manipulation of quantitatively controlled characters are important objectives in both basic and applied genetic research programmes. The identification of specific regions of the genome which enhance the expression of quantitatively controlled characters may allow the development of more efficient plant breeding strategies. The theoretical basis for interpreting the association of marker loci with quantitative trait loci (QTL) has been outlined by Thoday (1961), Mather and Jinks (1982), Geldermann (1975), Tanksley, Medina-Filho and Rick (1982) and Beckman and Soller (1983). Essentially the theory exploits the fact that the marker locus identifies a chromosomal segment and enables that segment to be monitored in subsequent generations of crossing or selfing. Recently, Paterson et al. (1988) have outlined a method based on interval mapping which assess the effects of genomic segments located between pairs of marker loci, rather than the effects associated with individual loci. However, reports of the association between marker loci and quantitative traits were first presented by Sax (1923) who found an association between seed size and alleles influencing seed colour in Phaseolus. Other earlier reports include those of Rasmusson (1933), Everson and Schaller (1955), Spicket and Thoday (1966) and Breese and Mather (1957, 1960).

The importance of character dissection in plants has been recognised for some time but has been hampered by the lack of suitable marker loci. The development of gel electrophoretic techniques for separating proteins and multiple forms of enzymes, isozymes, has provided considerable impetus for the genetic characterisation of a wide range of plant species (Tanksley and Orton, 1983). Isozymes can be considered as genetic markers, which are well distributed over the genome and interact in a co-dominant manner. Isozyme loci are therefore well suited to the mapping of genes controlling quantitative traits. Isozymes have been used to map QTL in tomato (Tanksley, MedinaFilho and Rick, 1981; Vallejos and Tanksley, 1983; Weller, Soller and Brody, 1988), soybean (Graef, Fehr and Cianzo, 1989), and maize (Stuber, Goodman and Moll, 1982; Stuber, Edwards and Wendel, 1987; Edwards, Stuber and Wendel, 1987). In the case of tomato and soybean interspecific crosses were used to maximise the number 
of potential polymorphic markers available in the segregating crosses. Although the level of electrophoretic variability for enzyme coding loci in maize is higher than in tomato and soybean the parents used to investigate the effects of isozyme loci on QTL were again selected to maximise the number of allelic differences in the segregating crosses. These experiments were successful in identifying regions of the genome which can account for substantial fractions of the phenotypic variance in the $\mathrm{F}_{2}$ generation. However, this approach may not predict which blocks of genes will be of use in intervarietal transfers in plant breeding programmes.

It has been stressed by Brown, Munday and Oram (1988) that there is no a priori reason to assume that an isozyme locus will predict the level of expression of a given quantitative trait. A high level of linkage disequilibrium between the marker locus and the quantitative trait is required. The majority of the studies to-date have focussed on the use of $F_{2}$ and backcross generations to measure the effects of isozyme loci on QTL. This approach, although valid, assumes that there will be no further breakdown of linkage groups in subsequent selfing and crossing. It is likely that further rounds of gametogenesis will result in the attainment of linkage equilibrium. This indicates that the early segregating generations of a cross may not represent the optimal strategy for the complete evaluation of linkage between an isozyme locus and a quantitative trait locus. Further complications arising from the use of $F_{2}$ and backcross generations include the difficulty of obtaining accurate estimates of the environmental and genetical component of variance. The presence of dominance can also introduce a bias to the estimates obtained and the unit of replication is based on single plants (Powell, Caligari and Thomas, 1986). Intergenotypic competition is also an important factor influencing the assessment of quantitative traits (Powell et al., 1985).

Many of the problems associated with the assessment of segregating populations can be overcome by the use of doubled haploid (DH) lines. Haploids are sporophytes which contain the gametic chromosome number (Nitszche and Wenzel, 1977). Haploidisation of diploids and subsequent chromosome doubling to produce $\mathrm{DH}$ allows the development of completely homozygous individuals from heterozygous parents in a single generation. Efficient methods of haploid production exist in barley and populations of doubled haploids have been produced by the $H$. bulbosum technique (Kasha and Kao, 1970). Doubled haploids extracted from the $F_{1}$ generations are likely to exhibit a higher linkage disequilibrium relative to other generations due to the reduced opportunities for recombination. These families also represent fixed, homozygous genotypes and may therefore be extensively tested in replicated experiments. DH therefore provide a valuable genetical resource which may be used to test for associations between marker loci and QTL. In this paper we present the first report of the use of $\mathrm{DH}$ to monitor the effect of selection for isozyme and protein loci on QTL in barley.

\section{MATERIALS AND METHODS}

\section{Plant material}

Sixty-six doubled haploids (DH) were produced by the $H$. bulbosum technique from the $\mathrm{F}_{1}$ hybrid of a barley (Hordeum vulgare) cross, Dissa $x$ Sabarlis. The parents, $D H$ lines and $F_{1}$ hybrids were grown in a randomised complete block field experiment with two replicates in 1986. Within a block each family was represented by a row of up to ten seeds, sown at $5 \mathrm{~cm}$ spacing, with a wheat guard at each end of the row. Rows were $22.5 \mathrm{~cm}$ apart. After harvest, sheaves were returned to the laboratory and five randomly chosen plants from each row were scored for:

1. Final height, measured from the base of the plant to the collar in $\mathrm{cm}(\mathrm{Ht})$.

2. Number of grains per ear on the main stem (GN).

3. Yield of grain on the main stem (MSW).

4. Weight of the main stem straw (WS).

5. Number of fertile tillers per plant (TN).

6. Thousand grain weight, calculated from 2 and 4, above (TGW).

7. Grain yield from the whole plant, single plant yield (SPY).

8. Weight of straw from the whole plant, straw weight $(\mathrm{SW})$.

\section{Electrophoretic enzyme assays}

Proteins, including isozymes, were separated by horizontal isoelectric focusing in polyacrylamide gels. Table 1 gives details of the systems used.

\section{RESULTS}

Examples of the protein and isozyme polymorphism detected in the parents (Dissa and Sabarlis) are shown in fig. 1. The marker loci 
Table 1 List of markers, marker symbols, gene symbols, tissue used, $p \mathrm{H}$ gradient of IEF gel and assay reference

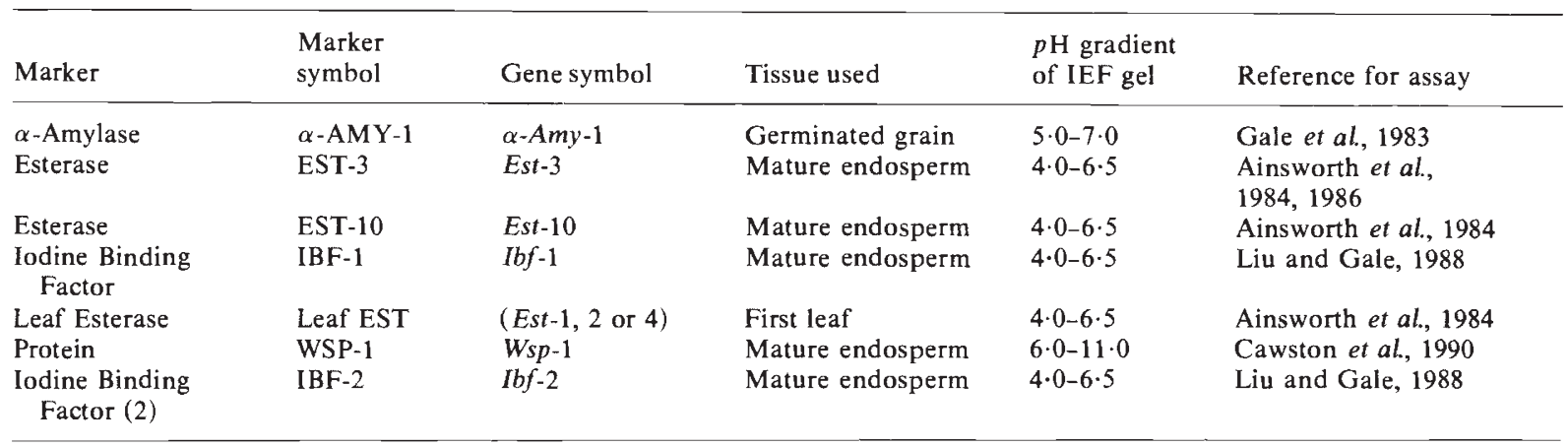

examined covered the whole chromosome complement but only seven were polymorphic and were located on five out of the seven barley chromosomes. Table 2 gives the chromosome locations of all the systems studied. Chromosome nomenclature is based on homoeology (Dewey, 1984) thus chromosomes $1,2,3,4,5,6$ and 7 correspond to barley chromosome numbers $5 \mathrm{H}, 2 \mathrm{H}, 3 \mathrm{H}, 4 \mathrm{H}$, $7 \mathrm{H}, 6 \mathrm{H}$ and $1 \mathrm{H}$ respectively. The segregation of alleles at each locus was tested against the expected $1: 1$ ratio. None of the isozymes tested deviated significantly from the expected ratio, although in the case of IBF-1 an excess of Dissa phenotypes was observed. Esterase loci have been mapped to

\section{PROTEIN POLYMORPHISMS FOR DISSA(D) \& SABARLIS(S)}

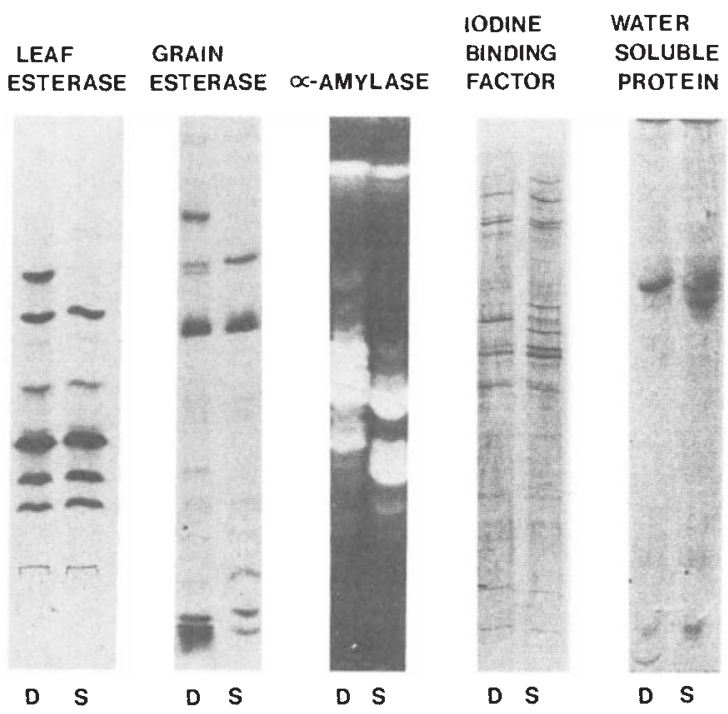

Figure 1 Protein polymorphism detected in the parental genotypes (Dissa and Sabarlis) for: Leaf esterase, grain esterase, $\alpha$-amylase, iodine-binding factor and watersoluble protein. the long arm of homoeologous group 3 chromosomes in the Triticeae (Ainsworth, Gale and Baird, 1986; Hvid and Nielson, 1977). The joint segregation analysis is given in table 3 . The alleles at each individual locus segregate in the expected $1: 1$ ratio. However, the joint segregation item is significant $(P<0.001)$ indicating that the leaf and endosperm loci are linked on $3 \mathrm{IL}$ with a recombination value of $0.24 \pm 0.05$

A primary objective of this study was to determine if specific marker loci (isozymes) affect any of the quantitative traits measured. The means and standard errors for the parental $F_{1}$ hybrid and $\mathrm{DH}$ genotypes are given in table 4 . For each trait measured the mean scores for each allelic class at the isozyme and protein loci in the $\mathrm{DH}$ population was calculated. The difference between the mean values for the alternative alleles at each locus is given in table 5 . In the case of Est-10 there were significant differences between groups for GN, MSW and WS. For leaf esterase there were significant differences between groups for: Ht, MSW, WS and TGW. Similarly, classification of alleles at the $\alpha$-Amy-1 locus results in significant differences between groups for: GN, MSW and SPY. For IBF-2 there were significant differences between groups for: GN, MSW and TGW. Two variates, GN and TGW exhibited significant differences between classes when selected on the basis of protein profile at the WSP locus. Clearly, selection of alleles at biochemical loci can influence the expression of quantitative trait loci. It is also of interest to note that individual marker loci can influence the expression of more than one quantitative trait locus. For example the $\alpha-A m y-1$ locus significantly affects three out of the eight traits scored:

Comparison of the parental and $F_{1}$ hybrid means (table 4) allows us to predict whether the QTL contributed from each parent will have a 
Table 2 Chromosomal location and segregation ratios for marker loci monitored in the barley doubled haploid population

\begin{tabular}{|c|c|c|c|c|}
\hline \multirow{2}{*}{$\begin{array}{l}\text { Isozyme and } \\
\text { protein markers symbols }\end{array}$} & \multirow{2}{*}{$\begin{array}{l}\text { Chromosomal location* } \\
\mathrm{L}=\text { long arm } \\
\mathrm{S}=\text { short arm }\end{array}$} & \multicolumn{2}{|c|}{ Isozyme phenotype } & \multirow{2}{*}{$\begin{array}{l}\chi_{(1)}^{2} \\
1: 1\end{array}$} \\
\hline & & Dissa & Sabarlis & \\
\hline EST-10 & $3 \mathrm{~L}$ & 34 & 32 & 0.06 \\
\hline EST-3 & $7 \mathrm{~S}$ & 33 & 33 & 0.00 \\
\hline$\alpha$-AMY-1 & $6 \mathrm{~L}$ & 33 & 33 & 0.00 \\
\hline IBF-1 & 4 & 40 & 26 & $2 \cdot 97$ \\
\hline Leaf EST & $3 \mathrm{~L}$ & 36 & 30 & 0.55 \\
\hline WSP-1 & 2 & 32 & 34 & 0.06 \\
\hline IBF-2 & Not located & 35 & 31 & $0 \cdot 24$ \\
\hline
\end{tabular}

* Triticeae homoeologous groups.

Other grain isozymes (with chromosomal location) which showed no polymorphism between Dissa and Sabarlis included $\beta$-amylase (4), glucose phosphate isomerase ( 1 and 3 ), peroxidase ( 2 ), phosphoglucomutase

(4) and superoxide dismutase (2).

Table 3 Joint segregation analysis for leaf and endosperm esterase loci on chromosome 3

\begin{tabular}{llll}
\hline \multicolumn{3}{l}{ Leaf } \\
\cline { 2 - 4 } Endosperm Est -10 & Dissa & \multicolumn{2}{l}{ Sabarlis } \\
\cline { 2 - 4 } Dissa & 27 & 7 & \\
Sabarlis & 9 & 23 & 0.06 \\
\hline Segregation for endosperm esterase alleles & 1 & 0.55 \\
Segregation for leaf esterase alleles & 1 & $17 \cdot 52^{* * *}$ \\
Joint segregation & & 1 & $18 \cdot 13$ \\
Total & & 3 & \\
\hline
\end{tabular}

$P=0.24 \pm 0.05$

*** $P<0.001$. positive or negative effect on the character measured. Thus for TGW we would anticipate that the Sabarlis genotype would make a positive contribution to the expression of this character. Reference to table 5 indicates that a number of examples may be identified in which the expression of QTL is in the opposite direction to these predicted by the parental values. Selection for the Dissa leaf esterase phenotype results in a $\mathrm{DH}$ population which has a significantly greater TGW value than the Sabarlis genotypes.

Since the chromosomal location of the genes Est-10 (Hvid and Nielson, 1977) and leaf esterase, which probably represents one of the closely linked

Table 4 Mean scores for the parents (Dissa and Sabarlis), $F_{1}$ hybrid and doubled haploid (DH) population

\begin{tabular}{|c|c|c|c|c|c|c|c|c|c|}
\hline \multirow[b]{2}{*}{ Genotype } & \multicolumn{9}{|c|}{ Quantitative trait } \\
\hline & $n$ & $\mathrm{Ht}$ & GN & MSW & WS & $\mathrm{TN}$ & TGW & SW & SPY \\
\hline Sabarlis & 50 & $80 \cdot 6 \pm 0.97$ & $27 \cdot 3 \pm 0 \cdot 41$ & $1.208 \pm 0.033$ & $0.986 \pm 0.033$ & $4 \cdot 6 \pm 0 \cdot 28$ & $43 \cdot 9 \pm 0 \cdot 70$ & $3 \cdot 87 \pm 0 \cdot 26$ & $4 \cdot 2 \pm 0 \cdot 27$ \\
\hline$F_{1}$ & 88 & $88 \cdot 6 \pm 1 \cdot 17$ & $26 \cdot 59 \pm 0 \cdot 65$ & $1.641 \pm 0.032$ & $1 \cdot 306 \pm 0 \cdot 031$ & $4 \cdot 5 \pm 0 \cdot 24$ & $62 \cdot 4 \pm 0 \cdot 71$ & $4 \cdot 54 \pm 0 \cdot 34$ & $5 \cdot 5 \pm 0 \cdot 35$ \\
\hline $\mathrm{DH}$ & 66 & $80 \cdot 1 \pm 0 \cdot 88$ & $34 \cdot 3 \pm 1 \cdot 64$ & $1 \cdot 324 \pm 0.042$ & $1.022 \pm 0.035$ & $3 \cdot 5 \pm 0 \cdot 17$ & $42 \cdot 4 \pm 1 \cdot 37$ & $3 \cdot 91 \pm 0 \cdot 20$ & $4 \cdot 5 \pm 0 \cdot 20$ \\
\hline
\end{tabular}

Table 5 Difference between mean values for alternative alleles at isozyme loci

\begin{tabular}{lcccccrrr}
\hline Isozyme & Ht & GN & MSW $\left(10^{3}\right)$ & WS $\left(10^{3}\right)$ & TN & TGW & SW & SPY \\
\hline EST-10 & $1 \cdot 28$ & $3 \cdot 11^{*}$ & $128 \cdot 20^{* *}$ & $-8 \cdot 17^{* *}$ & $0 \cdot 00$ & $0 \cdot 64$ & $0 \cdot 31$ \\
EST-3 & $1 \cdot 34$ & $2 \cdot 25$ & $33 \cdot 90$ & $45 \cdot 90$ & $0 \cdot 31$ & $1 \cdot 69$ & $0 \cdot 01$ \\
Leaf EST & $-3 \cdot 13^{* *}$ & $1 \cdot 04$ & $93 \cdot 20^{*}$ & $-87 \cdot 10^{* *}$ & $0 \cdot 01$ & $-2 \cdot 46^{*}$ & $0 \cdot 27$ & $0 \cdot 10$ \\
$\alpha$-AMY-1 & $1 \cdot 40$ & $-4 \cdot 64^{* * *}$ & $-135 \cdot 10^{* * *}$ & $48 \cdot 20$ & $0 \cdot 30$ & $0 \cdot 12$ & $0 \cdot 51$ & $0 \cdot 72^{*}$ \\
IBF-1 & $0 \cdot 10$ & $2 \cdot 70$ & $36 \cdot 00$ & $-15 \cdot 00$ & $0 \cdot 06$ & $1 \cdot 22$ & $0 \cdot 00$ & $0 \cdot 22$ \\
IBF-2 & -1.98 & $-6 \cdot 95^{* * *}$ & $-131 \cdot 00^{* *}$ & $-10 \cdot 00$ & $0 \cdot 01$ & $-3 \cdot 33^{* *}$ & $0 \cdot 05$ & $0 \cdot 42$ \\
WSP-1 & 1.08 & $3 \cdot 96^{* *}$ & $59 \cdot 00$ & $-16 \cdot 00$ & $0 \cdot 17$ & $2 \cdot 20^{*}$ & $0 \cdot 12$ & $-0 \cdot 04$ \\
\hline
\end{tabular}

The negative sign (-) indicates examples where differences between groups are not in agreement with the predicted phenotype based on parental and $F_{1}$ hybrid performance. 
Table 6 Mean values for 4 marker classes produced by two linked isozyme loci Est-10 and leaf esterase on chromosome 3

\begin{tabular}{lllll}
\hline & \multicolumn{2}{l}{ Genotypic class } & & \\
\cline { 2 - 5 } $\begin{array}{l}\text { Morphological } \\
\text { trait }\end{array}$ & Parent 1 & Recombinant 1 & Recombinant 2 & Parent 2 \\
& DD & DS & SD & SS \\
\hline Ht & 82.4 & 74.9 & $80 \cdot 1$ & 79.4 \\
GN & 35.5 & 37.2 & $32 \cdot 8$ & 32.7 \\
MSW & 1.403 & 1.310 & 1.259 & 1.263 \\
WS & 1.095 & 0.934 & 0.962 & 0.987 \\
TN & 3.6 & 3.8 & 3.8 & 3.6 \\
TGW & 43.4 & 38.4 & 42.6 & 41.8 \\
SW & 4.20 & 3.90 & 3.86 & 3.82 \\
SPY & 4.82 & 4.58 & 4.47 & 4.43 \\
\hline
\end{tabular}

Est-1, Est-2 or Est-4 genes (Kahler and Allard, 1970) have been established it is feasible to examine the effects of a recombination event occurring between these two loci on the long arm of chromosome 3I. Since the DH were extracted from the $F_{1}$ hybrid we can classify the population into four groups representing the parental and recombinant gametes. The mean scores for each genotypic class produced in this way are given in table 6. The analyses of variance for these data, which includes the orthogonal contrasts, are given in table 7 . There are significant differences between the parental and recombinant gametes for $\mathrm{Ht}$ and WS. The two parental genotypes differ significantly for Ht, MSW, WS. The two recombinant genotypes (classes) differ significantly for Ht and TGW.

The expected mean squares may be used to obtain estimates of $D$, the additive genetic variance for the $\mathrm{DH}$ families. This is the heritable portion of the phenotypic differences between homozygotes and is the fixable portion of the heritable variation. For all the characters measured there were significant levels of additive genetic variation and this reflects the genetic variation available for manipulation. The extent of the genetic variation associated with allelic variation at the individual loci is given in table 8. In the case of SPY over 9 per cent of the genetic variation available for manipulation can be accounted for by allelic variation at the $\alpha$-Amy-1 locus and is illustrated graphically in fig. 2. Selection of the Sabarlis $\alpha$ Amy-1 isozyme phenotype results in a higher frequency of greater yielding DH genotypes.

\section{DISCUSSION AND CONCLUSIONS}

The mapping of components of polygenic systems depends on the ability to detect the effects of allelic differences which are independent of the variation associated with genetic segregation and environmental variation (Thompson and Thoday, 1979).

Table 7 Analysis of variance for the four marker classes produced by two linked isozyme loci Est-3 and leaf esterase on chromosome 3

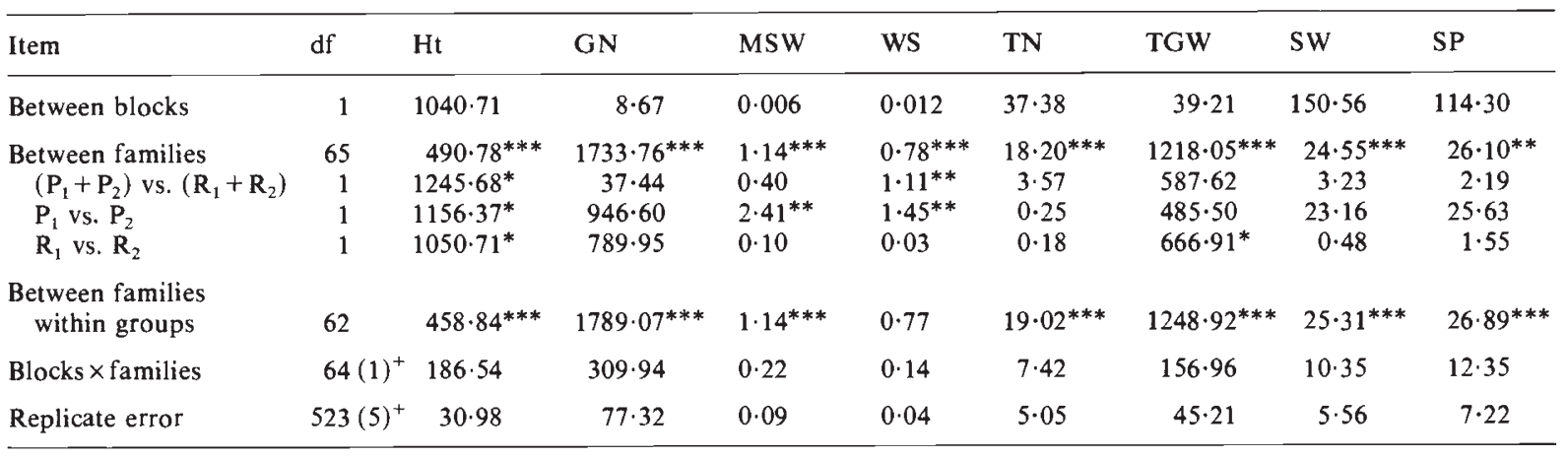

$+=$ number of missing values

$* P<0.05$.

** $P<0.01$

*** $P<0.001$. 
Table 8 Estimates of the percentage additive genetic variation associated with allelic differences at isozyme loci in a doubled haploid population

\begin{tabular}{ll}
\hline $\begin{array}{l}\text { Isozyme } \\
\text { locus }\end{array}$ & $\begin{array}{l}\text { Percentage of additive genetic variance } \\
\text { associated with a given character }\end{array}$ \\
\hline Est -10 & MSW $(2 \cdot 2)$, WS $(0 \cdot 8)$ \\
Leaf Est & Ht $(5 \cdot 7)$, MSW $(1 \cdot 19)$, WS $(1 \cdot 1)$, TGW $(0 \cdot 0)$ \\
$\alpha-A m y-1$ & GN $(2 \cdot 1)$, MSW $(3 \cdot 3)$, SPY $(9 \cdot 4)$, \\
Ibf-1 & GN $(6 \cdot 6)$, MSW $(2 \cdot 8)$, TGW $(0 \cdot 9)$, \\
$W s p-1$ & GN $(1 \cdot 0)$, TGW $(0 \cdot 0)$ \\
\hline
\end{tabular}

Isozymes meet these requirements and allow the effects of individual chromosomal regions to be examined. However, the concept of using mapped, monogenic markers to examine the underlying basis of quantitative variation is not new and this approach was pioneered in Drosophila genetics (Breese and Mather, 1957, 1960; Thoday, 1961). The availability of codominant markers has allowed an expansion in this area of research, particularly in crop plants (Tanksley and Orton, 1983).

Our results demonstrate that by selecting the isozyme phenotypes one can significantly affect the expression of certain QTL in barley. Of particular relevance is the predictive capacity of the isozyme profile. By examining the parental and $F_{1}$ hybrid scores one could predict in which direction a particular phenotype, based on isozyme selection would be biased. Several cases were detected where the selection method produced effects opposite to that predicted by the parental contributions. These cases probably reffect gene dispersion in the parents and may represent genes underlying transgressive segregation (Tanksley et al., 1982). Estimates of the genetic variation associated with individual loci were also calculated. In general, the percentage variation is small and this agrees with information reported for the association of effects of isozyme loci on QTL in maize (Stuber et al., 1987). However, in barley the $\alpha$-Amy-1 locus on chromosome 6 was associated with over 9 per cent of the variation for grain weight. Allelic variation at this locus makes a large contribution to the variation for SPY (fig. 2). This is reflected in the higher number of recombinant $\mathrm{DH}$ that exceed a given standard. If we calculate the number of $\mathrm{DH}$ that exceed a mean SPY of $5.0 \mathrm{gms}$, in the case of DH with the Dissa $\alpha$-Amy-1 phenotype we observe 8 such recombinants. However, when we use the Sabarlis $\alpha-A m y-1$ phenotype as an indirect selection tool we observe that 17 exceed the standard.

Dissa Sabarlis

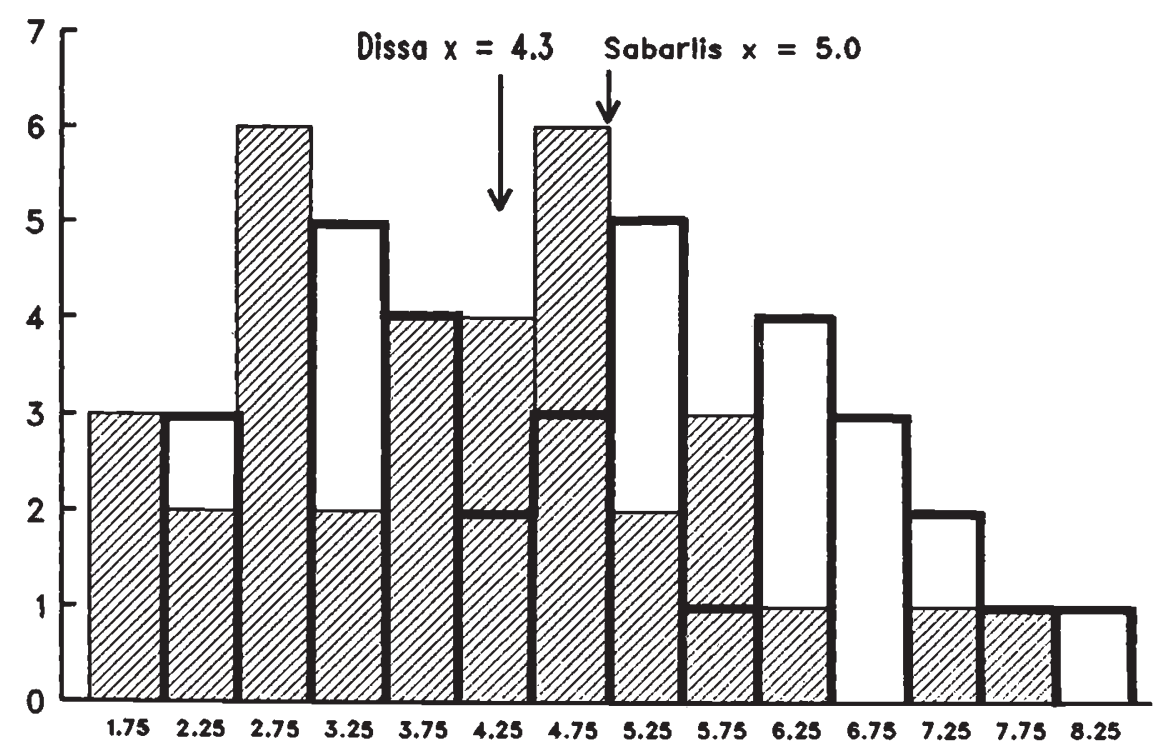

Figure 2 Frequency distribution for the character single plant yield (SPY) based on the Dissa and Sabarlis $\alpha$-Amy-1 isozyme phenotype. 
This demonstrates that selection of DH based on $\alpha-A m y-1$ phenotypes can shift the frequency distribution of recombinant inbreds in a positive, favourable direction.

Bailey (1975) and Burr et al. (1988) have outlined the advantages of recombinant inbred lines in gene mapping. These include the fact that recombinant inbred lines represent a permanent population that can be used indefinitely for mapping. Thus new loci may be continually added to the linkage map. The intra-chromosomal mapping of loci may be accomplished using $\mathrm{DH}$ families. The segregation of alleles at loci in these generations have the same expectations as backcross data and none of the markers deviated significantly from the expected 1:1 ratio. Maximum likelihood methods may be used to calculate the linkage intensity (Mather, 1938). Using this approach we were able to map the Est-10 and leaf esterase loci intra-chromosomally (table 3 ). Inbred families can be evaluated in many different environments and more accurate estimates of genetic parameters can be obtained (Mather and Jinks, 1982). These advantages apply with equal force to doubled haploids. Indeed, a comparison of $\mathrm{DH}$ and recombinant inbred lines may allow the basis of gene action to be investigated. An association between a marker locus and a quantitative trait locus could be due to pleiotrophy and/or linkage disequilibrium. Since the linkage bias in recombinant inbred lines will be less than that found in samples of DHs derived from $F_{1}$ hybrids a comparison of the two samples derived from common parents may allow true estimates of the degree of association between marker loci and QTL to be obtained. In addition, DH offer the possibility of controlling the level of recombination since families may be extracted from any generation (Caligari and Powell, 1986). The potential problem of recombination between a marker locus and a QTL can be circumvented by the use of $\mathrm{DH}$.

Additional marker loci would increase the applicability and power of marker based selection schemes. For example, the availability of genetic markers which are known to map to specific chromosomes will allow us to assess how much recombination occurs during various breeding strategies. Perhaps more importantly one can start to investigate the consequences of such recombinational events. Restriction fragment length polymorphisms (RFLPs) have been used to generate high density linkage maps in tomato (Tanksley, Mutschler and Rick, 1987) and maize (Helentjaris, 1987). The exploitation of such systems in barley will allow the variability available in the gene pool to be exploited to its full potential. The DH approach outlined in this manuscript will play an increasingly important role in relating variation detected at the protein and nucleic acid level to phenotypic variation observed at the whole plant level.

Acknowledgements The authors would like to thank $\mathrm{Mr} \mathrm{A}$. Cassidy, Mr R. Keith and Mrs J. Lyon for technical support.

\section{REFERENCES}

AINSWORTH, C. C., GALE, M. D. AND BAIRD, S. 1984. The genetic control of grain esterases in hexaploid wheat. 2. Allelic variation. Theor. Appl. Genet., 68, 219-226.

Ainsworth, C. C., Miller, T. E. AND GALE, M. D. 1986. The genetic control of grain esterases in hexaploid wheat. 2. Homoeologous loci in related species. Theor. Appl. Genet., 72, 219-225.

BAILEY, D. W. 1975. Recombinant inbred strains and bilineal congenic strains. In Foster, H. J., Small, J. D. and Fox, J. E. (eds) The Mouse in Biochemical Research, vol. 1, Academic Press, New York, pp. 223-239.

BECKMAN, J. S. AND SOLLER, M. 1983. Restriction fragment length polymorphisms in genetic improvement: methodologies, mapping and costs. Theor. Appl. Genet., $67,35-43$.

BREESE, E. L. AND MATHER, K. 1957. The organisation of polygenic activity within a chromosome in Drosophila. I. Hair characters. Heredity, 11, 373-395.

BREESE, E. L. AND MATHER, K. 1960. The organisation of polygenic activity within a chromosome in Drosophila. II. Viability. Heredity, 14, 375-400.

BROWN, A. H. D., MUNDAY, J. AND ORAM, R. N. 1988. Use of isozyme-marked segments from wild Barley (Hordeum spontaneum) in barley breeding. Pl. Breeding, 100, 280-288.

BURR, B., THOMPSON, K. H., ALBERTSON, M. C. AND STUBER, C. W. 1988. Gene mapping with recombinant inbreds in maize. Genetics, 118, 519-526.

CALIGARI, P. D. S. AND POWELL, W. 1986. Investigations into the linkage of genes controlling individual quantitative characters in spring barley. Can. J. Genetics 28, 63-68.

CAWSTON, D., POWELL, W. AND FORSTER, B. P. 1990. The use of iso-electric focussing for varietal identification in barley Ann. Appl. Biol. (in press).

DEWEY, D. R. 1984. The genomic system of classification as a guide to intergeneric hybridisation with the perennial Triticeae. In Gustafson, J. P. (ed.) Gene Manipulation in Plant Improvement, Plenum, New York, pp. 209-279.

EDWARDS, M. D., STUBER, C. W. AND WENDEL, J. F. 1987. Molecular-marker facilitated investigations of quantitative trait loci in maize. I. Numbers, genome distribution and types of gene action. Genetics, 116, 113-125.

EVERSON, E. H. AND SCHALLER, C. W. 1955. The genetics of yield differences associated with own barbing in the barley hybrid (Lion $\times$ Atlas $^{10}$ ) $\times$ Atlas. Argon. J., 47, 276-280.

GALE, M. D., LAW, C. N., CHOJECKI, A. J. AND KEMPTON, R. A. 1983. Genetic control of $\alpha$ amylase production in wheat. Theor. Appl. Genet., 64, 309-316.

GELDERMANN, H. 1975. Investigations on inheritance of quantitative characters in animals by gene markers. I. Methods. Theor. Appl. Genet., 46, 319-330. 
GRAEF, G. L., FEHR, W. R. AND CIANZO, S. R. 1989. Relationship of isozyme genotypes to quantitative characters in soybean. Crop. Sci., 29, 683-688.

HELENTJARIS, T. 1987. A genetic linkage map for maize based on RFLPs. Trends in Genetics Vol. 3, 8, 217-221. Elsevier Publications.

HVID, S. AND NIELSON, E. 1977. Esterase isoenzyme variants in barley. Hereditas, $87,155-162$.

KAHLER, A. L. AND ALLARD, R. W. 1970. Genetics of isozyme variants in barley. I. Esterases. Crop. Sci., 10, 444-448.

KASHA, K. J. AND KAO, K. N. 1970. High frequency haploid production in barley (Hordeum volgare L.). Nature, London, 225, 874-876.

LIU, C. J. AND GALE, M. D. 1980. Three new enzyme systems (IBF-1, MAL-1 and MDH-3) in wheat. Proceedings Seventh International Wheat Genetics Symposium, Cambridge, pp. $555-560$

MATHER, K. (1938). The Measurement of Linkage in Heredity. Methuen and Co. Ltd., London.

MATHER, K. AND JINKS, J. L. 1982. Biometrical Genetics. Chapman and Hall, London.

NITSZCHE, W. AND WENZEL, G. 1977. Haploids in Plant Breeding. Verlag Paul Parey, Berlin and Hamburg.

PATERSON, A. H., LANDER, E. S., HEWITT, J. D., PETERSON, S., LINCOLN, S. E. AND TANKSLEY, S. D. 1988. Resolution of quantitative traits into Mendelian factors by using a complete linkage map of restriction fragment length polymorphisms. Nature, 335, 721-726.

POWELL, W., CALIGARI, P. D. S., GOUDAPPEL, P. D. AND THOMAS, W. T. B. 1985. Competitive interactions in monoculture and mixtures of spring barley. Theor. Appl. Genet., 71, 443-450.

POWELL, W., CALIGARI, P. D. S. AND THOMAS, W. T. B. 1986. Comparison of spring barley lines produced by single seed descent, pedigree inbreeding and doubled haploidy. Plant Breeding, 97, 138-146.

RASMUSSON, J. M. 1983. A contribution to the theory of quantitative character inheritance. Hereditas, 18, 245-261.

SAX, K. 1923. The association of size differences with seed-coat pattern and pigmentation in Phaseolus vulgaris. Genetics, $8,552-560$.
SPICKETT, S. E. AND THODAY, J. M. 1966. Regular responses to selections. III. Interaction between located polygenes. Genet. Res., Camb, 7, 96-121.

STUBER, C. W., EDWARDS, D. AND WENDEL, J. F. 1987 Molecular marker-facilitated investigation of quantitative trait loci in maize. II. Factors influencing yield and its component traits. Crop Sci, 27, 639-648.

STUBER, C. W., GOODMAN, M. M. AND MOLL, R. H. 1982. Improvement of yield and ear number resulting from selection at allozyme loci in a maize population. Crop Sci., 22, 737-740.

TANKSLEY, S. D., MEDINA-FILHO, H. AND RICK, C. M. 1981. The effect of isozyme selection on metric characters in an interspecific backcross of tomato-basis of an early screening procedure. Theor. Appl. Genet., 60, 291-296.

TANKSLEY, S. D., MEDINA-FILHO, H. AND RICK, C. M. 1982. Use of naturally occurring enzyme variation to detect and map genes controlling quantitative traits in an interspecific backcross of tomato. Heredity, 49(1), 11-25.

TANKSLEY, S. D. AND ORTON, T. J. (eds) 1983. Isozymes in Plant Breeding and Genetics. Amsterdam: Elsevier.

TANKSLEY, S. D., MUTSCHLER, M. A. AND RICK, C. M. 1987. Linkage map of the tomato (Lycopersicon esculentum) $(2 \mathrm{n}=$ 24). In O'Brien, S. J. (ed.) Genetic Maps 1987. A compilation of linkage and restriction maps of genetically studied organisms. (Cold Spring Harbor, NY.)

THODAY, J. M. 1961. Location of polygenes. Nature, 191, 368370.

THOMPSON, J. M. AND THODAY, J. M. 1979. Quantitative Genetic Variation. Academic, New York.

VALLEJOS, C. E. AND TANKSLEY, S. D. 1983. Segregation of isozyme markers and cold tolerance in an interspecific backcross of tomato. Theor. Appl. Genet., 66, 241-247.

WELLER, J. I., SOLLER, M. AND BRODY, T. 1988. Linkage analysis of quantitative traits in an interspecific cross of tomato (Lycopersicon esculentum $\times L$. pimpinellifolium) by means of genetic markers. Genetics, 118, 329-339. 